\title{
Development of a Commercial Screed Mortar with Low OPC Content by Incorporation of Biomass Fly Ash
}

\author{
Marinélia N. Capela ${ }^{1, * \mathbb{D}}$, David M. Tobaldi ${ }^{1} \mathbb{D}$, Luís A. C. Tarelho ${ }^{2} \mathbb{D}$, Maria P. Seabra ${ }^{1} \mathbb{D}$ and João A. Labrincha ${ }^{1}$ \\ 1 Department of Materials and Ceramic Engineering, CICECO_Aveiro Institute of Materials, \\ University of Aveiro, 3810-193 Aveiro, Portugal; david.tobaldi@ua.pt (D.M.T.); pseabra@ua.pt (M.P.S.); \\ jal@ua.pt (J.A.L.) \\ 2 Department of Environment and Planning, CESAM-Centre for Environmental and Marine Studies, \\ University of Aveiro, 3810-193 Aveiro, Portugal; 1tarelho@ua.pt \\ * Correspondence: marinelia.capela@ua.pt
}

Citation: Capela, M.N.; Tobaldi, D.M.; Tarelho, L.A.C.; Seabra, M.P.; Labrincha, J.A. Development of a Commercial Screed Mortar with Low OPC Content by Incorporation of Biomass Fly Ash. Appl. Sci. 2021, 11, 9630. https://doi.org/10.3390/ app11209630

Academic Editor: Fernanda Andreola

Received: 19 September 2021

Accepted: 13 October 2021

Published: 15 October 2021

Publisher's Note: MDPI stays neutral with regard to jurisdictional claims in published maps and institutional affiliations.

Copyright: (c) 2021 by the authors. Licensee MDPI, Basel, Switzerland. This article is an open access article distributed under the terms and conditions of the Creative Commons Attribution (CC BY) license (https:// creativecommons.org/licenses/by/ $4.0 /)$.
Featured Application: Substitution of 17 wt.\% of Ordinary Portland Cement by biomass fly ash in the formulation of a commercial screed mortar.

Abstract: Substitute Ordinary Portland Cement (OPC) by biomass fly ash (BFA) reduce the environmental impact produced by cement-based materials, and at the same time, decreased the economic and environmental burden associated with the landfilling of this waste. This study aims to evaluate the recycling of BFA as supplementary cementitious materials (SCMs) in a commercial screed mortar formulation. Two BFA varieties, both resulting from fluidized bed combustion of forest residues, were used to replace 17, 50, and $67 \mathrm{wt} . \%$ of OPC. The influence of simple pre-treatment processes of the BFA, such as sieving and grinding, in the fresh and hardened state properties of the mortars, was evaluated. The BFAs were characterized in terms of chemical (XRF) and mineralogical (XRD) composition, particle size distribution (laser diffraction-COULTER) and morphology (SEM). The prepared formulations were characterized in terms of workability, mass loss upon curing, bulk density, sorptivity (by immersion and capillary), flexural and compressive strength and durability to 25 freeze-thaw cycles. Both of the BFAs are potential SCMs. Substitution of $17 \mathrm{wt} \%$ OPC with BFA complied with the product technical requirements for compressive and flexural strength (10 and $3 \mathrm{MPa}$, respectively), with the ground and sieved and just sieved BFAs perform slightly better than the as-received BFA.

Keywords: biomass fly ash; green buildings; mortar; supplementary cementitious materials; sustainability; waste recycling

\section{Introduction}

The production of Ordinary Portland Cement (OPC) involves: (i) very high temperatures, usually above $1450^{\circ} \mathrm{C}$, consequently an enormous energy consumption [1-3]; (ii) the utilization of large quantities of non-renewable natural raw materials [1,3], mostly limestone and dolomite (as calcium sources) and marls, clays or shale (as silica and alumina sources) [1]; (iii) generation of particulate material [1,3], starting in mining process [1]; and (iv) significant $\mathrm{CO}_{2}$ emissions [1-6]. Being mostly generated on the calcination (decomposition of limestone) $[1,2,6]$ but also from the consumption of electricity (air coolers and ball mills) [1,2] and fossil fuels (preheater, calciner and kiln) [1,2,6]. Worldwide those emissions are around 8 to $10 \%$ of the anthropogenic global $\mathrm{CO}_{2}$ emissions, and it is expected to grow [5]. To limit the rise in global temperatures this century to less than $2{ }^{\circ} \mathrm{C}$ above preindustrial levels the International Energy Agency has issued a technology roadmap for reducing $\mathrm{CO}_{2}$ emissions in the cement industry through 2050 [7]. The manufacture of $\mathrm{OPC}$ is then not considered an environmentally friendly process [1]. Producers are being 
confronted to reduce their environmental impact, which has led to many studies aimed at reducing the environmental footprint of cement-based materials.

The substitution of OPC by supplementary cementitious materials, especially byproducts or wastes of distinct industrial processes, in the formulation of cement-based products might be a way to reduce its environmental footprint. Nowadays, one of the main supplementary cementitious materials used is siliceous fly ash (FA) [5,8], fundamentally because of its pozzolanic reactivity, which is a by-product of coal combustion in electric and thermal-electric power stations for heat and power production [8]. The pozzolanic reactivity is the ability that the material has to react, at ambient temperature, with the clinker hydration by-product $\mathrm{Ca}(\mathrm{OH})_{2}$ forming compounds with binding potential [9]. This property has been linked to the material's chemical composition, particle size, shape and surface texture, and degree of crystallinity [9]. $\mathrm{SiO}_{2}$ and $\mathrm{Al}_{2} \mathrm{O}_{3}$ present in FA can react with $\mathrm{Ca}(\mathrm{OH})_{2}$ during cement hydration to form hydrated calcium silicate (C-S-H) and hydrated calcium aluminate (C-A-H). Both compounds contribute to strength improvement [10]. Other supplementary cementitious materials can possess hydraulic activity, meaning that they can chemically react with water, set and harden [11]. FA have also been used with success in the development of alkali-activated binders [12-15] a topic that as gaining increasing interest for the development of more sustainable building materials [13-15] alternatives to those based on OPC [14,15].

Due to the implementation of decarbonization policies in the power sector, such as the roadmap for transforming the EU into a competitive low carbon economy by 2050, published by the European Commission [16], availability of FA from coal combustion will predictably decrease in the near future $[17,18]$. In pulp and paper production plants enormous quantities of FA are produced from biomass combustion in bubbling fluidized bed boilers, for heat and power production. Worldwide, only for power production, it was estimated that in 2018 were generated 10 million tons of biomass ash [11]. This inorganic solid waste has been looked at as a candidate to substitute coal FA $[17,18]$, however, most of it is still being disposed in landfills $[3,6,18,19]$. Nevertheless, this substitution might not be simple since physical characteristics and chemical and mineralogical composition [4] of biomass fly ash (BFA) differs from those of coal FA. Another important issue is that BFA characteristics differ from plant to plant due to the large variability of fuel blends used, added additives, combustion temperature [17,20], installed combustion technology [4,19-21] and used air pollution control devices [19-21]. Even in the same plant BFA can show temporal variation in their characteristics [3] mainly due to fluctuations in the daily biomass blends used. In terms of management practices, this variability constitutes a problem because is almost impossible to establish a general application [22].

The use of BFA, as OPC substitute on mortars, has been studied by several research groups. Rajamma et al., 2009 [4] replaced, in cement pastes and mortars, OPC Type I (42.5 R) by 10, 20 and $30 \mathrm{wt} . \%$ of BFA resulting from the combustion of forest residues (mainly eucalyptus wastes resulting from logging and wood processing activities). Dried $\left(60^{\circ} \mathrm{C}\right)$ and sieved $(75 \mu \mathrm{m})$ BFA was used, and the prepared samples were cured for 28 days. For $20 \mathrm{wt} . \%$ of OPC substitution the mechanical strength of the specimens was around 75\% of the reference mortar and was taken as acceptable. A strong strength deterioration was noticed for larger replacement amounts. Additionally, the relative high contents of carbon, chlorides, and sulphates in BFA limit the substitution rate. The presence of chlorides and sulphates in cement-based materials can deteriorate the microstructure and, consequently, the durability of products. The presence of organic matter interferes with the setting time due to the tendency to adsorb water.

In a later work, Rajamma et al., 2015 [23], starting from the same formulations used in the aforementioned work [4], evaluated the fresh and hardened (for shorter and longer curing times) state properties of the cement pastes and mortars. The increase of the OPC substitution by BFA promotes a rise in water demand and setting time and a decrease in the hydration temperature of the pastes. Comparing with the standard mortar composition, the substitution of OPC by BFA decreased the flexural and compressive strength of the 
samples cured for 7, 28, and 90 days. However, for longer curing times (90 days) the difference was shortened.

Pavlíková et al. [3] studied the partial OPC (CEM I 42.5 R) replacement (10, 15 and $20 \mathrm{wt} . \%)$ by a dried $\left(70^{\circ} \mathrm{C}\right)$ milled mixture of BFA and bottom bed ash, from wood chips combustion, in mortars that were cured for 28 days. The milling process provided a fineness similar to that of OPC. All the prepared mortars show good functional properties. The addition of $10 \mathrm{wt} . \%$ BFA improved the flexural and compressive strength of the mortars, for the other two additions it was observed a slight decrease in both properties. Leaching tests were performed on the mortars and it was verified the presence of only trace amounts of chlorides, nitrates, and sulphates.

Tosti et al. [6] prepared mortars with 20 and $40 \mathrm{wt} . \%$ of OPC (CEM I $42.5 \mathrm{~N}$ ) substituted for three different types BFA. The technical performance of the mortars was influenced by the type and percentage of BFA used, and it was verified that increasing the OPC replacement rates the strength decreased. Substituting $20 \mathrm{wt} . \%$ of OPC by BFA from fluidized bed combustion of Ca-rich biomass, provide mortars with compressive strength compliant with the requirement for structural concrete application of $42.5 \mathrm{MPa}$ after 28 days of curing. For the same substitution rate, the use of BFA from the combustion of wood pellets in a pulverized fuel installation provide mortars with the lower compressive strength, but that complies with the requirement for non-structural applications (32.5 MPa).

In a recent work [18], Fořt et al. used as-received BFA generated from the combustion of wood chips in a fluidized bed furnace as a substitute of OPC (CEM I $42.5 \mathrm{R}$ ) in a mortar formulation. The substitution rate varied from 10 to $70 \mathrm{wt} . \%$. Up to $30 \mathrm{wt} . \%$ of OPC replacement by BFA the mortars obtained after 28 days of curing kept their functional properties. Increasing the amount of incorporated BFA induces a decrease in the mechanical strength of the samples. Longer curing times (90 and 180 days) improve the mechanical properties of mortars.

Ohenoja et al. [24] evaluated the benefits of using pre-treated (air-jet classification and grinding) FA as a substitute of $20 \mathrm{wt} . \%$ of OPC in cement-based mortars (CEM I 52.5 R-SR5). Three FA types generated from the combustion in bubbling fluidized bed boilers of different mixtures of fuels (peat, wood and wastes) were evaluated. The authors concluded that the mortars with $20 \mathrm{wt} . \%$ of classified and ground FA reach 80 and $90 \%$ of the control sample's compressive and flexural strength, respectively.

In this work, the substitution of OPC, in a commercial screed mortar formulation, by 17,50 and $67 \mathrm{wt} . \%$ of two BFA, both resulting from fluidized bed combustion of forest residues, was evaluated. The influence of simple pre-treatment: sieving at $2 \mathrm{~mm}$ (BFA1 and BFA2), sieving at $63 \mu \mathrm{m}$ (BFA1_S and BFA2_S) and grinding followed by sieving at $63 \mu \mathrm{m}$ (BFA1_GS and BFA2_GS) was also evaluated in the fresh and hardened state properties of the mortars. The prepared formulations were characterized in terms of workability, mass loss upon curing, bulk density, sorptivity (by immersion and capillary), flexural and compressive strength and durability to freeze-thaw cycles. The main objective was to maximize the BFA percentage and, consequently, minimize the OPC content, ensuring that products meet the technical requirements for the target application.

\section{Materials and Methods}

\subsection{Raw Materials}

The standard composition of the screed is the one commercially available and that is composed by: $15 \mathrm{wt} . \%$ OPC (CEM II/A-L $42.5 \mathrm{R}), 15 \mathrm{wt} . \%$ limestone $(1.5<\Phi<3.0 \mathrm{~mm}$ ) and two natural siliceous sands (35 wt.\% each) previously washed and calibrated, S1 $(0.1<\Phi<0.5 \mathrm{~mm})$ and S2 $(0.5<\Phi<1.2 \mathrm{~mm})$. Those materials were provided by SaintGobain Weber, Aveiro, Portugal. Two biomass fly ash (BFA) were tested as OPC substitutes, both furnished by a Portuguese pulp and paper producer (The Navigator Company, Aveiro, Portugal). One (BFA1) is generated in a biomass power station equipped with a bubbling fluidized bed boiler (BFBB) with an installed power of $49 \mathrm{MW}$. As fuel, residual forest biomass is used. The exact composition of the biomass blends used in the collection days is 
not known, but they are mainly composed of eucalyptus and pine treetops. Other species (grey willow, white poplar, Sydney golden wattle and silver wattle) are also present, but in minor quantities. The other BFA (BFA2) is produced in a biomass cogeneration plant that produces heat (process steam) and power, equipped with a BFBB and an installed power of $99 \mathrm{MW}$. As fuel, eucalyptus bark and minor amounts of knots are used. In both cases, the typical boiler temperature is around $825^{\circ} \mathrm{C}$ and sand is used as the bottom bed. It was observed that BFA1 and BFA2 present some temporal variability in their physical and chemical properties. To mitigate this problem, batches of ashes collected over three days of production were prepared for both references. The BFA batches were dried in a ventilated laboratory oven at $105^{\circ} \mathrm{C}$, and then sieved through a $2 \mathrm{~mm}$ mesh (Retsch AS200, Haan, Germany), to remove possible contaminations, such as organic matter (unburnt and burnt), metallic particles resulting from the boilers degradation or stones, derived from inappropriate harvesting procedures. Simple pre-treatment processes of BFA were tested: sieving through a $63 \mu \mathrm{m}$ mesh (Retsch AS200, Haan, Germany); or grinding in a vibratory disc mill (Retsch RS100, Haan, Germany) until the whole sample passed through the 63 $\mu \mathrm{m}$ mesh. Three powders, with different characteristics, were obtained for each BFA batch:

(i) BFA sieved at $2 \mathrm{~mm}-\mathrm{BFA} 1$ and BFA2;

(ii) BFA sieved at $63 \mu \mathrm{m}-\mathrm{BFA} 1 \_\mathrm{S}$ and BFA2_S;

(iii) BFA grounded and then sieved at $63 \mu \mathrm{m}-\mathrm{BFA1}$ _GS and BFA2_GS.

All the powders were stored in closed polypropylene opaque containers.

\subsection{Raw Materials Characterization}

The chemical composition of OPC and BFA samples was assessed by X-ray fluorescence (XRF) (Philips, X'Pert PRO MPD spectrometer, Almelo, The Netherlands) on a compressed powder pellet (10 $\mathrm{g}$ of sample was homogenized with five drops of polyvinyl alcohol, and further pressed to a standardized shape). The loss on ignition (LOI) at $1000{ }^{\circ} \mathrm{C}(15 \mathrm{~min}$ dwell time), of the dried sample, was also determined. The organic matter content of the BFA samples was determined according to ISO 1762:2001 [25] (firing at $525^{\circ} \mathrm{C}$ for $3 \mathrm{~h}$ ).

The particle size distributions were determined by laser diffraction (Beckman, Coulter LS230FM, Brea, CA, USA) employing the Fraunhofer model and the wet (water) procedure. Before the analysis, the samples were sonicated in water, for $5 \mathrm{~min}$, to avoid particles agglomeration.

OPC, BFA1 and BFA2 particles were observed by scanning electron microscopy (Hitachi, SU-70, Tokyo, Japan). Prior to SEM observation, the samples were coated with a carbon thin film (Emitech, K950, Fall River, MA, USA) to provide a conducting layer.

The mineralogical composition of BFA1 and BFA2 powders was evaluated by $X$ ray powder diffraction (XRD), at room temperature. The XRD was conducted on a $\theta / \theta$ diffractometer (Malvern, PANalytical, X'Pert Pro3, Almelo, The Netherlands), equipped with a fast RTMS detector (Malvern PANalytical, PIXcel 1D, Almelo, the Netherlands), with $\mathrm{Cu} \mathrm{K} \alpha$ radiation $\left(45 \mathrm{kV}\right.$ and $40 \mathrm{~mA}, 10-80^{\circ} 2 \theta$ range, with a virtual step scan of $0.026^{\circ} 2 \theta$, and virtual time per step of $100 \mathrm{~s}$ ). For this analysis, all powders were grounded in an agate mortar until the whole sample passed through a $63 \mu \mathrm{m}$ sieve.

\subsection{Screed Mortar Preparation}

The compositions of the prepared screeds (standard and with BFA incorporation) are presented in Table 1. The generic notation of samples is x_BFA, with $\mathrm{x}$ providing ready information on OPC wt.\% substitution by each BFA prepared powder. The water to binder $(\mathrm{OPC}+\mathrm{BFA})$ ratio $(\mathrm{w} / \mathrm{b})$ was kept constant $(0.67)$. Samples with $67 \mathrm{wt} . \%$ of the as received ashes (BFA1 and BFA2) were not prepared, due to the fact that their homogenization was impossible without changing the $\mathrm{w} / \mathrm{b}$ ratio. In the preparation, tap water was added to the previously blended solids and mixed (KitchenAid, Artisan 175PS, Benton Harbor, MI, USA) for $1 \mathrm{~min}$ at a low rotation speed (60 rpm). Then the mixer was stopped for $1 \mathrm{~min}$, to remove the material stuck to the edges of the bowl and place it again in the centre, and then turned on again for $1 \mathrm{~min}$ at the same speed. Prismatic mortar samples of $40 \mathrm{~mm} \times 40 \mathrm{~mm} \times 160 \mathrm{~mm}(\mathrm{~W} \times \mathrm{H} \times \mathrm{L})$ were prepared, by casting the mixtures into 
standard metallic moulds according to the EN 196-1:2005 [26]. Following the BS 82041:2003 [27] the specimens were cured, for two days in the mould, at $20^{\circ} \mathrm{C}\left( \pm 2{ }^{\circ} \mathrm{C}\right)$ with a relative humidity of $95 \%( \pm 5 \%)$. After that, the samples were taken out of the moulds and cured, for five days, at $20^{\circ} \mathrm{C}\left( \pm 2{ }^{\circ} \mathrm{C}\right)$ with a relative humidity of $95 \%( \pm 5 \%)$. Afterwards, the specimens were kept 21 days at $20^{\circ} \mathrm{C}\left( \pm 2{ }^{\circ} \mathrm{C}\right)$ with a relative humidity of $65 \%( \pm 5 \%)$, adding up a total of 28 curing days.

Table 1. Prepared compositions.

\begin{tabular}{|c|c|c|c|c|c|c|c|c|c|c|}
\hline \multirow{2}{*}{ Composition } & \multicolumn{10}{|c|}{ Raw Materials (g) } \\
\hline & Limestone & S1 & $\mathrm{S} 2$ & OPC & BFA1 & BFA1_S & BFA1_GS & BFA2 & BFA2_S & BFA2_GS \\
\hline Standard & 15.0 & 35.0 & 35.0 & 15.0 & - & - & - & - & - & - \\
\hline 17_BFA1 & 15.0 & 35.0 & 35.0 & 12.5 & 2.5 & - & - & - & - & - \\
\hline 50_BFA1 & 15.0 & 35.0 & 35.0 & 7.5 & 7.5 & - & - & - & - & - \\
\hline 17_BFA1_S & 15.0 & 35.0 & 35.0 & 12.5 & - & 2.5 & - & - & - & - \\
\hline 50_BFA1_S & 15.0 & 35.0 & 35.0 & 7.5 & - & 7.5 & - & - & - & - \\
\hline 67_BFA1_S & 15.0 & 35.0 & 35.0 & 5.0 & - & 10.0 & - & - & - & - \\
\hline 17_BFA1_GS & 15.0 & 35.0 & 35.0 & 12.5 & - & - & 2.5 & - & - & - \\
\hline 50_BFA1_GS & 15.0 & 35.0 & 35.0 & 7.5 & - & - & 7.5 & - & - & - \\
\hline 67_BFA1_GS & 15.0 & 35.0 & 35.0 & 5.0 & - & - & 10.0 & - & - & - \\
\hline 17_BFĀ2 & 15.0 & 35.0 & 35.0 & 12.5 & - & - & - & 2.5 & - & - \\
\hline 50_BFA2 & 15.0 & 35.0 & 35.0 & 7.5 & - & - & - & 7.5 & - & - \\
\hline 17_BFA2_S & 15.0 & 35.0 & 35.0 & 12.5 & - & - & - & - & 2.5 & - \\
\hline 50_BFA2_S & 15.0 & 35.0 & 35.0 & 7.5 & - & - & - & - & 7.5 & - \\
\hline 67_BFA2_S & 15.0 & 35.0 & 35.0 & 5.0 & - & - & - & - & 10.0 & - \\
\hline 17_BFA2_GS & 15.0 & 35.0 & 35.0 & 12.5 & - & - & - & - & - & 2.5 \\
\hline 50_BFA2_GS & 15.0 & 35.0 & 35.0 & 7.5 & - & - & - & - & - & 7.5 \\
\hline 67_BFA2_GS & 15.0 & 35.0 & 35.0 & 5.0 & - & - & - & - & - & 10.0 \\
\hline
\end{tabular}

\subsection{Screeds Characterization}

The consistency of the fresh screed mortars was measured in a flow table according to the EN 1015-3:1998 [28]. The mass loss during the 28 days of curing was calculated as the average of three measurements.

In the evaluation of the hardened ( 28 days curing) screeds three specimens per composition were tested. The density was calculated by measuring the specimen's dimensions and their mass. The percentage of water absorption was determined by immersing the dried (in an oven at $60^{\circ} \mathrm{C}$ until they reach a constant mass) specimens in distilled water for $24 \mathrm{~h}$. Absorption by capillarity was evaluated according to the EN 1015-18:2002 [29]. Three-point flexural and uniaxial compression tests were performed, at room temperature, using a Universal Testing Machine (Shimadzu, model AG-25 TA refresh, Kyoto, Japan; provided with a $20 \mathrm{kN}$ and $250 \mathrm{kN}$ load cell for three-point bending strength and uniaxial compression, respectively, running at a displacement rate of $0.5 \mathrm{~mm} / \mathrm{min}$ ).

\subsection{Evaluation of the Freeze-Thaw Resistance}

According to EN 998-2:2016 [30], the freeze-thaw resistance must be evaluated taking into account the conditions that the mortar will be subjected upon use. Therefore, to assess the durability of the selected compositions the specimens used on the flexural strength testing were subjected to 25 consecutive freeze-thaw cycles [31]. Each cycle consists of three steps:

(i) Immersion in distilled water for $24 \mathrm{~h}$ at $20 \pm 2{ }^{\circ} \mathrm{C}$;

(ii) Freezing at $-20 \pm 2{ }^{\circ} \mathrm{C}$ during $24 \mathrm{~h}$;

(iii) Drying at $50 \pm 2{ }^{\circ} \mathrm{C}$ throughout $24 \mathrm{~h}$.

These conditions can foresee the performance of the screed when exposed to outdoor extreme environmental conditions. Density, water absorption, and compressive strength of the mortars were analysed after 0, 5, 15 and 25 freeze-thaw cycles (at the end of thawed 
step), to quantify the decay caused by the cycles. In addition, a visual evaluation, and a morphological assessment with an optical microscope (Leica, EZ4HD, Wetzlar, Germany) of the specimen's surface was made. The experimental results obtained for these samples were compared with the ones obtained for the control samples (same age and stored in air at $\left.20 \pm 2{ }^{\circ} \mathrm{C}\right)$. Three specimens per composition were tested.

\section{Results and Discussion}

\subsection{Physicochemical Properties of the Raw Materials}

The chemical composition of OPC and biomass fly ash (BFA), as received and after the applied pre-treatment processes, obtained by $\mathrm{X}$-ray fluorescence (XRF), is presented in Table 2. For OPC, $\mathrm{CaO}, \mathrm{SiO}_{2}, \mathrm{Al}_{2} \mathrm{O}_{3}, \mathrm{SO}_{3}$ and $\mathrm{Fe}_{2} \mathrm{O}_{3}$ are the main components (their total amount represents $89.53 \mathrm{wt} . \%$ ) and the LOI value is $7.25 \mathrm{wt} . \%$. BFA1 main components are $\mathrm{SiO}_{2}\left(38.14\right.$ wt.\%), $\mathrm{CaO}\left(26.97\right.$ wt.\%), $\mathrm{Al}_{2} \mathrm{O}_{3}\left(11.86\right.$ wt.\%), and $\mathrm{K}_{2} \mathrm{O}(6.56$ wt.\%). $\mathrm{BFA} 2$ is also mainly composed by the same oxides but the amounts are different: $32.34 \mathrm{wt} . \% \mathrm{CaO}$, 21.79 wt. $\% \mathrm{SiO}_{2}, 9.28$ wt. $\% \mathrm{~K}_{2} \mathrm{O}$ and 8.74 wt. $\% \mathrm{Al}_{2} \mathrm{O}_{3}$. Fořt et al. [18] concluded that $\mathrm{BFA}$ from fluidized bed combustion of wood chips (composed mostly of softwoods, with minor amounts of hardwoods) contains $\mathrm{SiO}_{2}, \mathrm{CaO}$, and $\mathrm{Al}_{2} \mathrm{O}_{3}$ as main oxides. The same observation was reported by Rajamma et al. [4] for BFA from fluidized bed combustion of forest wastes, mostly eucalyptus. BFA1 chemical composition complies with both author's findings. $\mathrm{BFA} 2$ also presents $\mathrm{SiO}_{2}$ and $\mathrm{CaO}$ as major oxides compounds, but the $\mathrm{K}_{2} \mathrm{O}$ content, although very close, is superior to $\mathrm{Al}_{2} \mathrm{O}_{3}$. This fact can be due to differences in the biomass blends used as fuels and on combustion technologies as pointed by Ohenoja et al. [19]. BFA2 exhibits higher contents in $\mathrm{Na}_{2} \mathrm{O}(6.04 \mathrm{wt} . \%)$ and $\mathrm{Cl}$ (6.21 wt.\%) than BFA1 (1.34 wt.\% of $\mathrm{Na}_{2} \mathrm{O}$ and $1.12 \mathrm{wt} . \%$ of $\mathrm{Cl}$ ). The $\mathrm{SO}_{3}$ content is $3.74 \mathrm{wt} . \%$ for BFA2 and $2.41 \mathrm{wt} . \%$ for BFA1, and the LOI values are $10.48 \mathrm{wt} . \%$ and $6.05 \mathrm{wt} . \%$, respectively, for BFA2 and BFA1. From the XRF results, it can also be noticed that there are some compositional differences between the as received, and the sieved $(<63 \mu \mathrm{m})$ BFA. The sieved materials (BFA1_S and BFA2_S) exhibit higher $\mathrm{LOI}$ and $\mathrm{Cl}$ amounts and a smaller $\mathrm{SiO}_{2}$ content. $\mathrm{The}_{3} \mathrm{SO}_{3}$ amount is slightly higher for BFA1 and slightly smaller for BFA2. The larger particles existing in BFA result, essentially, from the contamination with bottom sand, which explains the smaller $\mathrm{SiO}_{2}$ amount in the sieved fraction $(<63 \mu \mathrm{m})$. On the contrary, the unburned materials exhibit small dimensions, which explains their higher content in this fraction. The chemical composition of BFA1_GS and BFA2_GS is the same as their parent powders BFA1 and BFA2, respectively, because the material was ground until everything went through the sieve.

Table 2 also present the sum of $\mathrm{SiO}_{2}, \mathrm{Al}_{2} \mathrm{O}_{3}$, and $\mathrm{Fe}_{2} \mathrm{O}_{3}$ amounts, which value is commonly used to assess the applicability of siliceous fly ash (FA) produced by burning pulverized coal, with or without co-combustion materials, according to EN 450-1:2012 [32]. Because of the lack of proper classification for BFA, as guidance, the standard of coal FA for use in concrete was used. According to this normative, in a pozzolanic material, the sum of $\mathrm{SiO}_{2}+\mathrm{Al}_{2} \mathrm{O}_{3}+\mathrm{Fe}_{2} \mathrm{O}_{3}$ contents must surpass $70 \mathrm{wt}$. \% [11]. For BFA1 this value is equal to $55.46 \mathrm{wt} . \%$, hence some pozzolanic activity is expected. Sieved BFA1 shows a lower amount (46.93 wt.\%). BFA2 shows a lower value (34.92 wt.\%), and sieving causes a further decrease (21.91 wt.\% for BFA2_S). Therefore, no relevant pozzolanic activity is expected.

The values of the $(\mathrm{CaO}+\mathrm{MgO}) / \mathrm{SiO}_{2}$ ratio are presented in Table 2. BFA2 exhibits a value of 1.69, thus higher than 1.4, which is, as pointed by some authors [33,34], the value that defines hydraulic activity of coal FA. The sieving promoted an enhancement of the hardening potential activity of BFA2. The hardening potential of BFA1 is smaller than that of BFA2. According to EN 197-1 [35], a material that has hydraulic activity must have a $(\mathrm{CaO}+\mathrm{MgO}) / \mathrm{SiO}_{2}$ ratio superior to one, and this might explain the hardening potential of BFA1_S [11,35]. We should remind that these values should be used for guidance, since EN197-1 is applied for coal FA. 
Table 2. Chemical composition, LOI, and particle size of OPC and BFA samples.

\begin{tabular}{|c|c|c|c|c|c|c|c|}
\hline $\begin{array}{l}\text { Chemical Composition } \\
\text { (wt.\%) }\end{array}$ & OPC & BFA1 & BFA1_S & BFA1_GS ${ }^{1}$ & BFA2 & BFA2_S & BFA2_GS ${ }^{1}$ \\
\hline $\mathrm{SiO}_{2}$ & 14.44 & 38.14 & 30.00 & 38.14 & 21.79 & 13.29 & 21.79 \\
\hline $\mathrm{CaO}$ & 64.25 & 26.97 & 31.93 & 26.97 & 32.34 & 25.74 & 32.34 \\
\hline $\mathrm{Al}_{2} \mathrm{O}_{3}$ & 4.01 & 11.86 & 11.48 & 11.86 & 8.74 & 5.64 & 8.74 \\
\hline $\mathrm{K}_{2} \mathrm{O}$ & 0.95 & 6.56 & 7.89 & 6.56 & 9.28 & 11.35 & 9.28 \\
\hline $\mathrm{Fe}_{2} \mathrm{O}_{3}$ & 3.36 & 5.45 & 5.45 & 5.45 & 4.40 & 2.99 & 4.40 \\
\hline $\mathrm{MgO}$ & 1.42 & 3.19 & 3.31 & 3.19 & 4.40 & 2.76 & 4.40 \\
\hline $\mathrm{SO}_{3}$ & 3.47 & 2.41 & 2.95 & 2.41 & 3.74 & 3.23 & 3.74 \\
\hline $\mathrm{Na}_{2} \mathrm{O}$ & 0.20 & 1.34 & 1.28 & 1.34 & 6.04 & 18.04 & 6.04 \\
\hline $\mathrm{P}_{2} \mathrm{O}_{5}$ & 0.04 & 1.33 & 1.35 & 1.33 & 1.30 & 0.86 & 1.30 \\
\hline $\mathrm{TiO}_{2}$ & 0.34 & 0.80 & 0.71 & 0.80 & 0.55 & 0.34 & 0.55 \\
\hline $\mathrm{MnO}$ & 0.05 & 0.54 & 0.67 & 0.54 & 0.91 & 0.75 & 0.91 \\
\hline $\mathrm{Cl}$ & 0.07 & 1.12 & 2.65 & 1.12 & 6.21 & 14.66 & 6.21 \\
\hline $\mathrm{SiO}_{2}+\mathrm{Al}_{2} \mathrm{O}_{3}+\mathrm{Fe}_{2} \mathrm{O}_{3}$ & & 55.46 & 46.93 & 55.46 & 34.92 & 21.91 & 34.92 \\
\hline$(\mathrm{CaO}+\mathrm{MgO}) / \mathrm{SiO}_{2}$ & & 0.79 & 1.17 & 0.79 & 1.69 & 2.14 & 1.69 \\
\hline LOI & 7.25 & 6.05 & 12.34 & 6.05 & 10.48 & 15.02 & 10.48 \\
\hline Mean particle diameter $(\mu \mathrm{m})$ & 15.89 & 306.40 & 21.95 & 14.64 & 30.91 & 17.71 & 9.30 \\
\hline \multicolumn{8}{|l|}{ Particle size fractions $(\mu \mathrm{m})$} \\
\hline D10 & 0.68 & 8.63 & 2.25 & 1.30 & 2.37 & 1.60 & 1.07 \\
\hline D50 & 11.66 & 260.50 & 17.20 & 11.39 & 19.05 & 12.53 & 6.20 \\
\hline D90 & 37.68 & 705.50 & 48.62 & 33.32 & 75.95 & 42.20 & 22.93 \\
\hline
\end{tabular}

${ }^{1}$ BFA1_GS and BFA2_GS chemical composition was assumed to be equal to their parent powders BFA1 and BFA2, respectively.

Significant amounts of alkali, earth-alkali, and $\mathrm{Cl}$ were detected in BFA samples. Alkaline earth (calcium, magnesium) and alkaline (sodium, potassium) sulphates can chemically react with the components of the cement, reducing mechanical properties of hardened bodies and causing volumetric changes. The $\mathrm{SO}_{3}$ content, in both used BFA is close than that of OPC, so it will not constitute a problem. The presence of chlorides might also reduce the mechanical strength of the hardened bodies by causing the appearance of efflorescence and, consequently, decreasing the durability, or by reaction with tricalcium aluminate $(\mathrm{C} 3 \mathrm{~A})$ and tetracalcium aluminoferrite $(\mathrm{C} 4 \mathrm{AF})$ forming chloroaluminates linked to the increase of expansion and porosity [36]. According to the EN 998-2:2016 [30], the $\mathrm{Cl}^{-}$ content of a mortar/concrete formulation should be lower than $0.1 \mathrm{wt} . \%$. The formulations developed with 17 and $50 \mathrm{wt} . \%$ of OPC replaced by BFA1 have $\mathrm{Cl}$ amounts below this limit. In the case of BFA1_S just the one with $17 \mathrm{wt} . \%$ does not overcome that limit. All the samples prepared with BFA2 have $\mathrm{Cl}$ amounts higher than $0.1 \mathrm{wt} . \%$. Commonly, despite the high processing temperature $\left(825^{\circ} \mathrm{C}\right)$, due to kinetic and mass transfer limitations [4], BFA has some organic matter. The organic matter contents of the BFA under study varies between 2.8 (BFA1_S) and 1.4 wt.\% (BFA2_S). BFA1_GS and BFA2_GS was assumed to be equal to their parent powders BFA1 and BFA2, respectively.

The particle size distribution of the materials under study are presented in Table 2 and in Figure 1. OPC particles $($ Dmean $=15.89 \mu \mathrm{m})$ are finer than BFA2 $($ Dmean $=30.91 \mu \mathrm{m})$ ones, but when comparing to BFA1 (Dmean $=306.40 \mu \mathrm{m}$ ) OPC presents a mean particle diameter one order of magnitude lower. The pre-treated (sieved at $63 \mu \mathrm{m}$ ) BFA has a mean particle diameter closer to OPC. BFA2 pre-treated fractions present a smaller mean particle diameter than BFA1: BFA2_S $17.71 \mu \mathrm{m}$, BFA2_GS $9.30 \mu \mathrm{m}$, BFA1_S $21.95 \mu \mathrm{m}$, and BFA1_GS $14.64 \mu \mathrm{m}$. The sieving narrowed the particle size distribution of BFA, becoming closer to that of OPC. The milling and sieving of BFA narrowed this distribution even further. The BFA particle size distribution plays an important role in their reactivity with the OPC constituents, as well in the compactness of the samples. It will also change the required amount of kneading water. Finer materials tend to be more reactive, and the mechanical strength might improve [36]. 

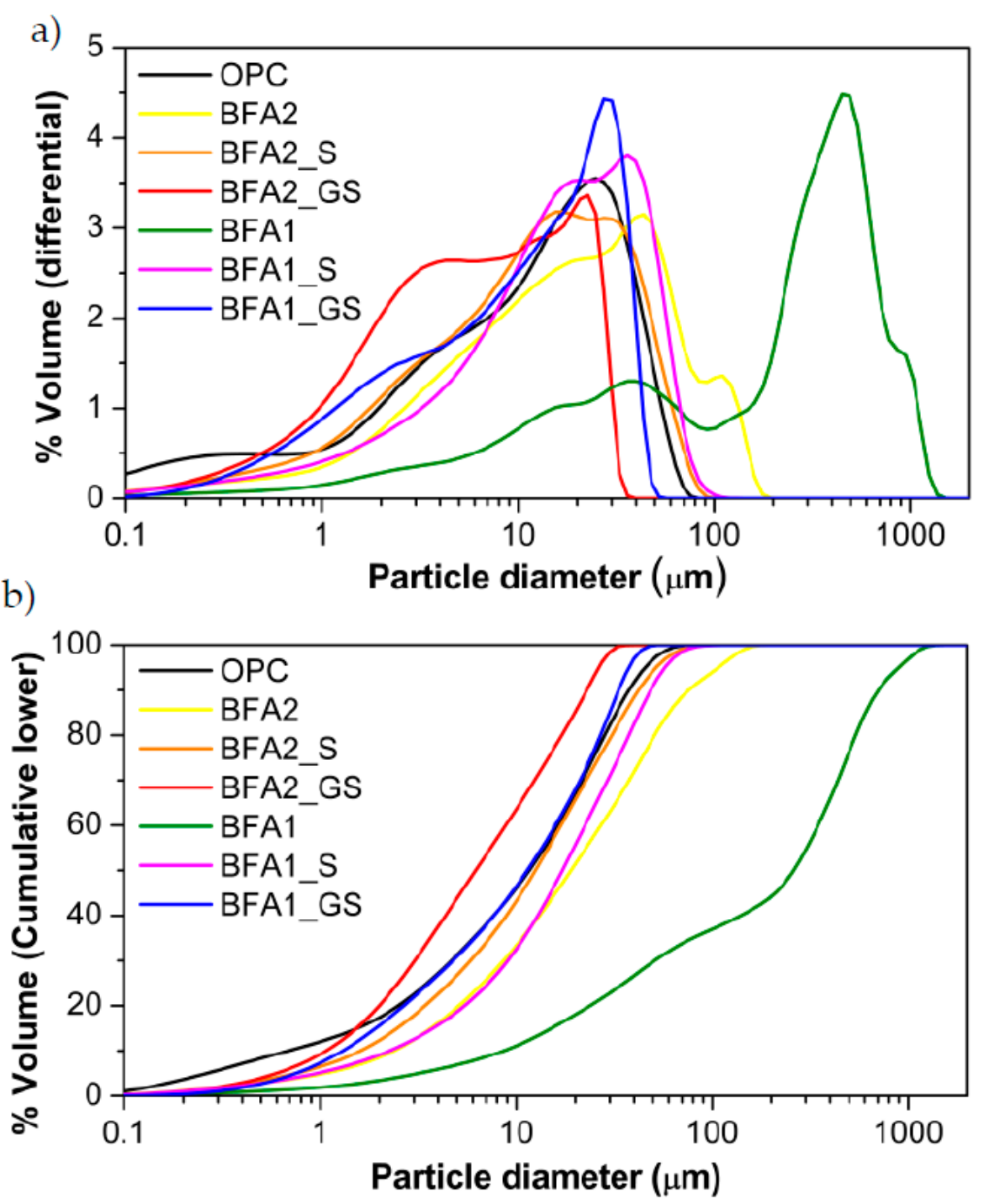

Figure 1. Particle size distribution (volume basis) of the OPC, and BFA as received and pre-treated: (a) differential, and (b) cumulative lower.

Figure 2 shows micrographs of OPC, BFA1 and BFA2, as received and pre-treated. The detail of the surface of the particles of OPC, BFA1 and BFA2 is patent in Figure 2a,c,d, respectively. BFA particles have a rougher surface than OPC ones. As-received BFA (BFA1Figure 2e and BFA2-Figure 2f) is composed of irregularly shaped particles with a broad particle size range (between only a few microns and more than $100 \mu \mathrm{m}$ ). OPC (Figure 2b) is constituted by smaller and less angular particles and a narrower size distribution when comparing to BFAs. In Figure $2 \mathrm{~g}$, $\mathrm{h}$ is clear the smaller particle size that results from the sieving procedure. Grinding and sieving lead to a BFA with a very different particle morphology. The mean particle diameter was decreased and the particle size distribution was narrowed (Figure 2i,j) by turning irregularly shaped particles into smaller and less angular ones, so more similar to OPC ones. These observations are in accordance with the Coulter results (Table 2 and Figure 1). 


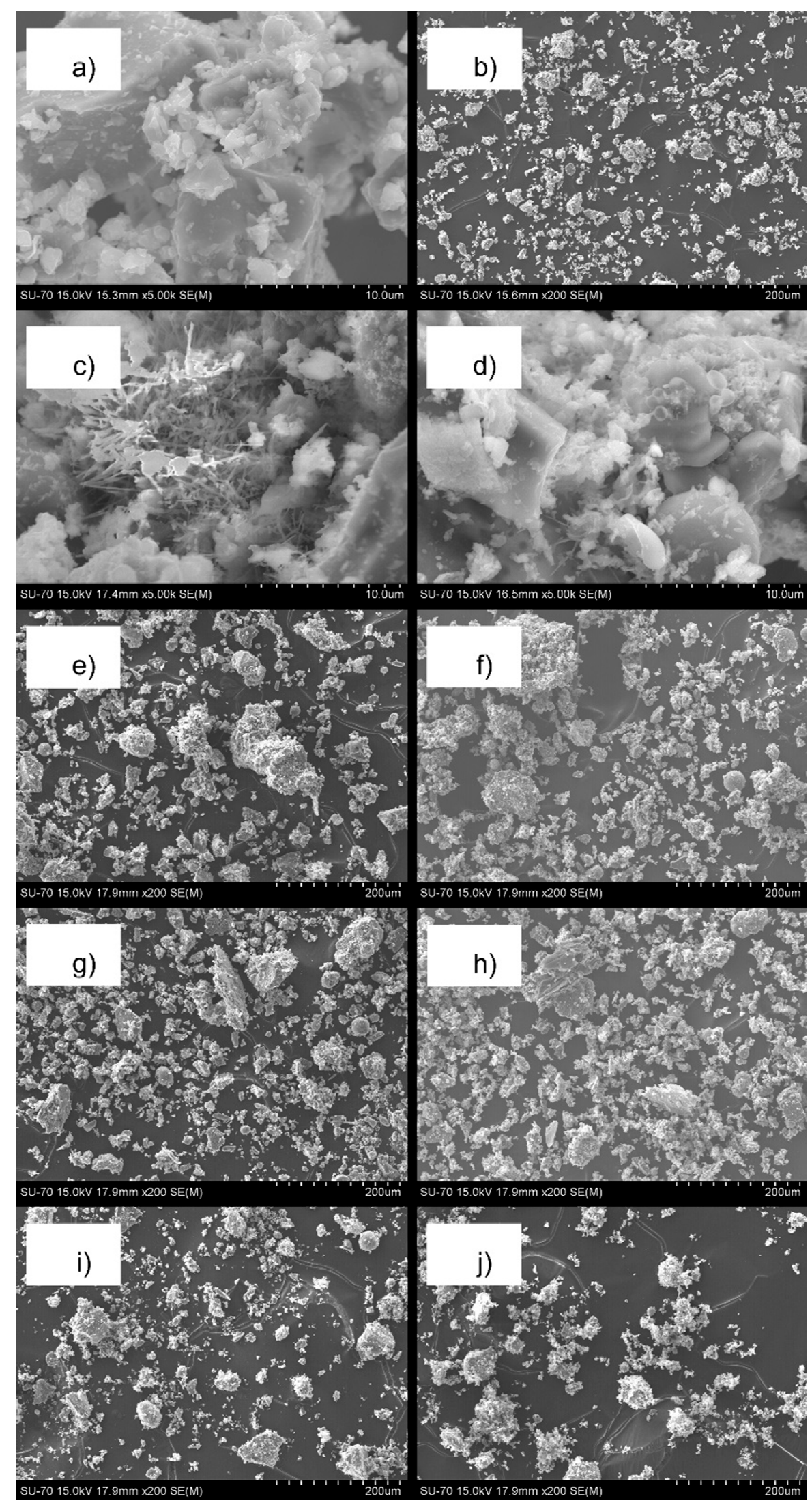

Figure 2. SEM micrographs of the materials under study: (a) OPC, (b) OPC, (c) BFA1, (d) BFA2, (e) BFA1, (f) BFA2, (g) BFA1_S, (h) BFA2_S, (i) BFA1_GS and (j) BFA2_GS. 
The XRD results showed that the main crystalline phases present in BFA1 and BFA2 samples are $\alpha$-quartz, calcite, microcline, muscovite and illite, which is in good agreement with XRF results. As pointed by Ohenoja et al. [19] the mineralogical composition of BFA from fluidized bed combustion depends on fuel and quantity of chemical additions, but quartz and calcite are commonly found $[4,18,19,36]$.

\subsection{Screeds Fresh and Hardened State Properties}

The binder to aggregate $(b / a=0.18)$ and the water to binder $(w / b=0.67)$ ratios were kept constant for all the prepared mixtures. The initial spread diameter was $100 \mathrm{~mm}$ for all the prepared compositions. The standard composition exhibited a final spread diameter of $109 \mathrm{~mm}$. For the compositions in which $17 \mathrm{wt} \%$ of OPC was replaced by BFA1, and for 50_BFA1_GS and 67_BFA1_GS, the values were slightly smaller (between 103 and $106 \mathrm{~mm}$ ). All the other compositions fell apart (did not flow) after the 15 strokes. All the mixtures prepared with BFA2 also fell apart, with exception of the ones prepared with BFA2_GS that presented final spread diameter values between 101 and $105 \mathrm{~mm}$, slightly smaller than the standard composition. Teixeira et al. [21] and Rajamma et al. [23] also verified that the spread diameter values decreased with the increase in OPC replacement by BFA. OPC substitution by as received and sieved BFA increased the water demand of the mixes. This tendency was reported by different authors $[4,18,19,23,37]$. BFA powders tend to retain water due to its irregular shape, size, and presence of organic matter [23], diminishing the mixture workability by reducing the amount of available kneading water. This leads to difficulties in the mixing process, increases the probability of pores occurrence and decreases the homogeneity and density of the samples [36]. These problems can be solved by adding plasticizers, not tried in the current study. All cured samples where OPC was replaced by as received or sieved BFA show higher water absorption values (are more porous) than the standard formulation (as will be discussed later). This result is partially caused by the poorer workability. The lower density of BFA $\left(2.54 \mathrm{~g} / \mathrm{cm}^{3}\right.$ [23] $)$ when compared to that of OPC $\left(3.15 \mathrm{~g} / \mathrm{cm}^{3}\right.$ [38]) and the intrinsic porosity of the ash particles also contribute to the observed decrease in the density of the samples. Experimentally it was noted, for both ashes (BFA1 and BFA2), that the milling process decreases the water demand of the mortars, as confirmed by the obtained slump values. The same fact was reported by Rissanen et al. [37]. This behaviour can be explained by the narrower particle size distribution (similar to the OPC), obtained after the referred pre-treatment (Table 2, Figures 1 and 2), and, as suggested by Rissanen et al. [37], the grinding process disintegrated the irregularly shaped particles and the agglomerates. The mixing is facilitated, and a better homogenization of the mixtures is achieved, while the compactness of the mortars is enhanced. Characteristics approach the ones of the standard formulation, even when a higher OPC percentage is replaced (67 wt.\%).

The mass loss upon curing for the compositions prepared with BFA1 and BFA2 powders are presented in Figure 3. On the seventh day of curing, most of the compositions where OPC was substituted by BFA1 present a higher mass loss than the standard composition. The opposite behaviour was observed for the samples prepared with the BFA2. The mass loss occurs, essentially, until the 14th curing day and the values are greater than the ones exhibited by the standard. The difference is bigger for the compositions prepared with BFA1 and the mass loss of the specimens tends to increase with BFA incorporation amount. This can be the result of the higher porosity and pore interconnectivity of these samples, as will be discussed later. 

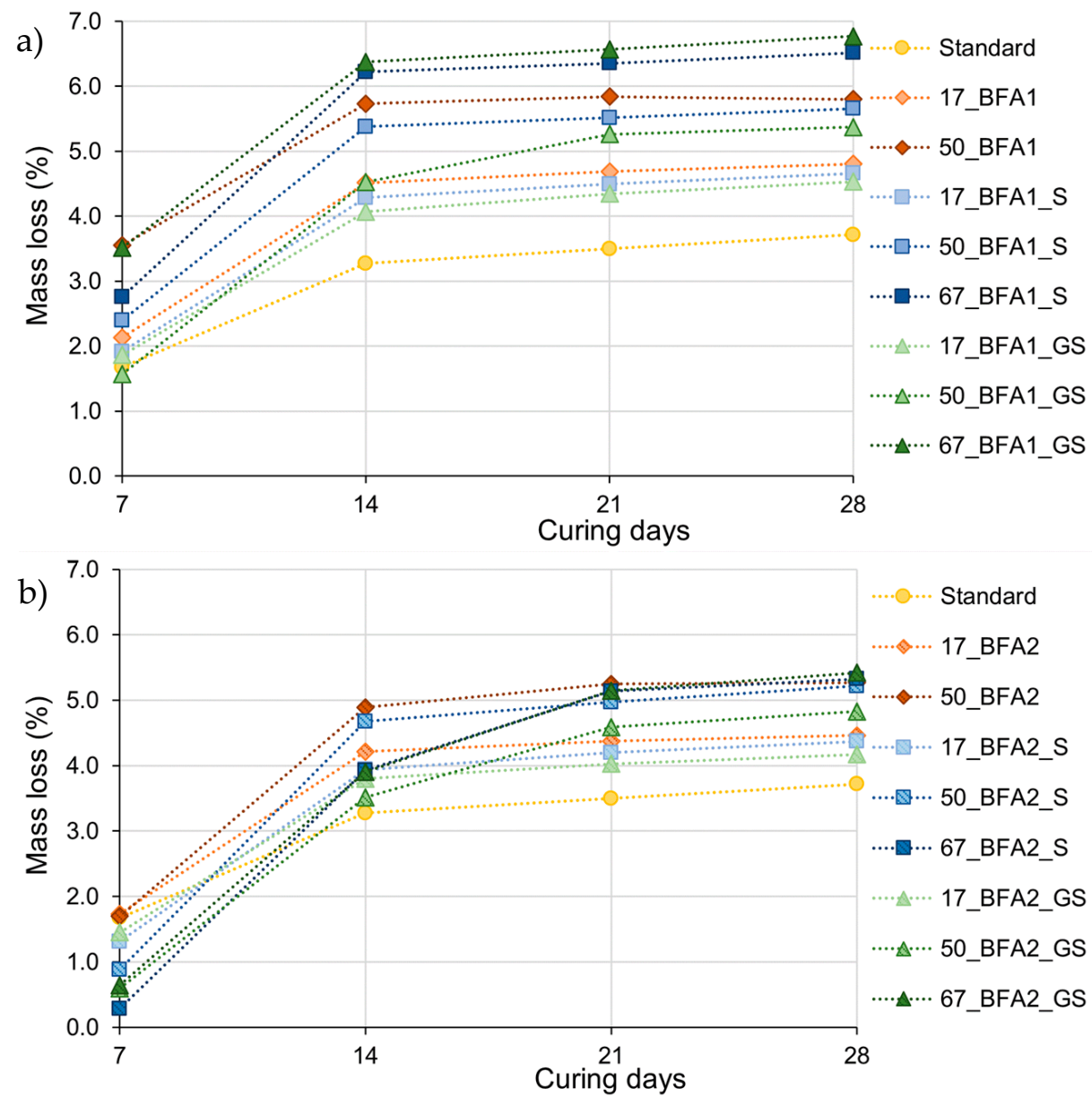

Figure 3. Mass loss upon curing for the compositions prepared with: (a) BFA1 powders, and (b) BFA2 powders.

Figure 4 shows the density of the prepared mortars cured for 28 days. The specimens in which $17 \mathrm{wt} . \%$ of OPC was replaced by BFA show densities close to the standard (maximum variation of $<5 \%$ ). The increase of OPC substitution from 17 to $67 \mathrm{wt} . \%$, promoted a slight decrease (maximum variation $<10 \%$ ). For the higher OPC substitution $(67 \mathrm{wt} . \%)$, the specimens prepared with the sieved ashes have lower densities $\left(1.77 \mathrm{~g} / \mathrm{cm}^{3}\right.$ for BFA1 and $1.75 \mathrm{~g} / \mathrm{cm}^{3}$ BFA2) than the ones prepared with the ground and sieved ashes $\left(1.85 \mathrm{~g} / \mathrm{cm}^{3}\right.$ for BFA1 and $1.89 \mathrm{~g} / \mathrm{cm}^{3}$ for BFA2). As pointed before, the milling process decreases the particle size $(14.64 \mu \mathrm{m}$ for BFA1_GS and $9.30 \mu \mathrm{m}$ BFA2_GS; $21.95 \mu \mathrm{m}$ for BFA1_S and $17.71 \mu \mathrm{m}$ for BFA2_S - see Table 2), and also lead to a decrease in the amount of elongated particles, so a more homogeneous mixture and a higher compaction degree is achieved in the samples prepared with the milled and sieved BFA. This observation is in line with Rissanen et al. [37] that referred that a denser packing can be achieved by using a wellgraded particle size distribution that allows smaller particles to fill the spaces between larger ones. 


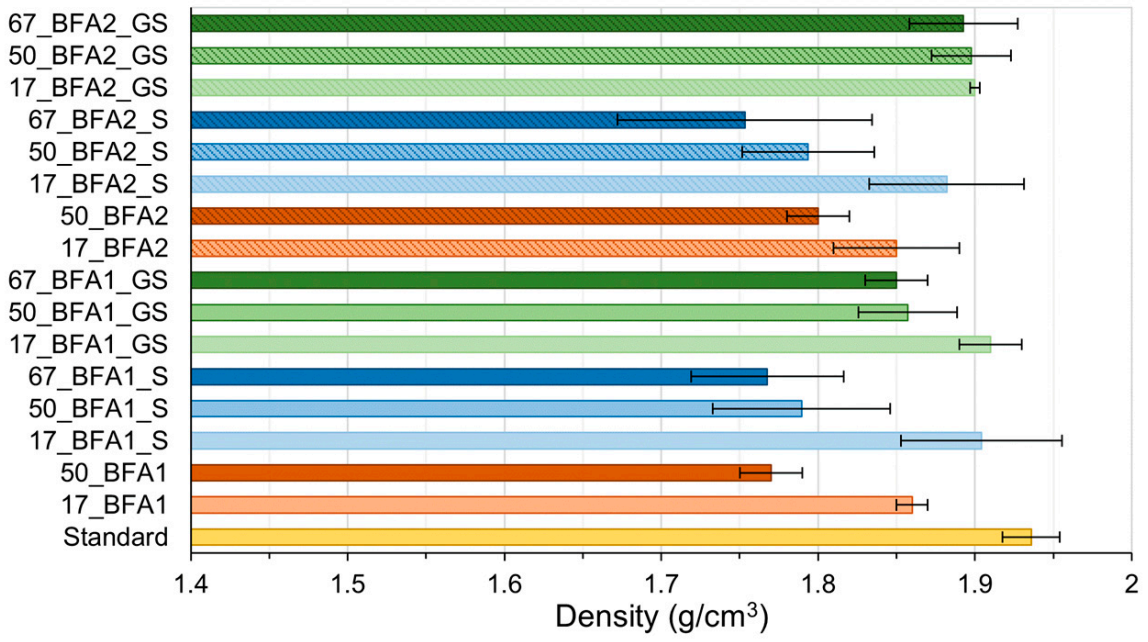

Figure 4. Density of the mortars prepared with BFA1 and BFA2 after curing for 28 days.

Figure 5 present the water absorption of the specimens by immersion after 28 days of curing. For all the prepared compositions, the water absorption values are higher than for the standard formulation. The increase in the percentage of OPC substitution by BFA causes an increment in the water absorption values of the samples, as a result of their higher porosity. The negative effect of the utilization of BFA on the mortar's porosity was also previously reported by Fořt et al. [18].

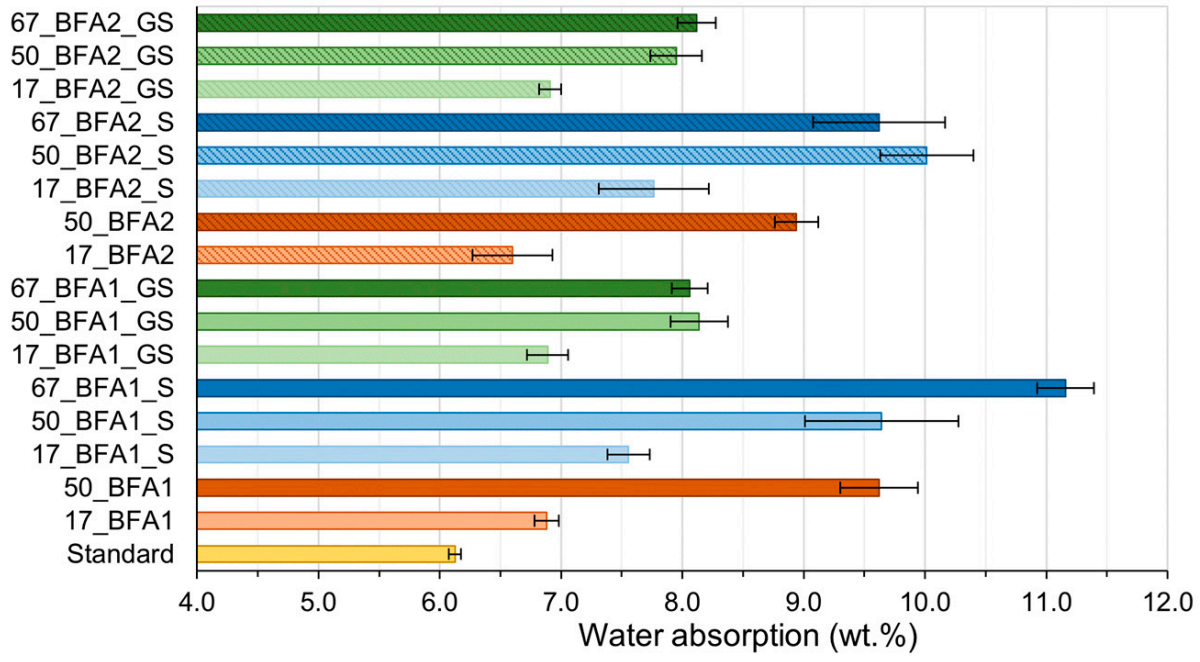

Figure 5. Water absorption of the mortars prepared with BFA1 and BFA2 powders after curing for 28 days.

The mass increase of the specimens with time, due to the water capillary absorption, is shown in Figure 6. The behaviour of samples with $17 \mathrm{wt} . \%$ of OPC substitution and the standard one is similar. However, the 17_BFA1_S and 17_BFA2_S samples exhibit a higher mass increase (after $90 \mathrm{~min}$ ) than the respective standard sample (4.8 for BFA1, 3.9 for BFA2 and $1.9 \mathrm{wt} . \%$ for the standard). For the same percentage of OPC substitution, the mass increase is higher for samples prepared with sieved ashes $(<63 \mu \mathrm{m})$ than those containing ground and sieved wastes. The same behaviour was observed for the water absorption by immersion (Figure 5), meaning that their porosity is higher and is interconnected. Similar behaviour was observed for the samples in which 50 and $67 \mathrm{wt} . \%$ of OPC was substituted by BFA. The higher content of smaller particles, present in the ground and sieved fractions, can fill the capillary pores reducing the water sorptivity by capillary action. Pavlíková et al. [3] study the effect of partial OPC replacement with a milled mixture of 
BFA and bottom bed ash (with a fineness similar to that of OPC) in the mortars average pore diameter. After a slight increase in the average pore diameter for $10 \mathrm{wt}$ \% substitution, the authors verified that for 15 and $20 \mathrm{wt} . \%$, the average pore diameter decreased. This finding was attributed to a partial filler effect of the ashes.
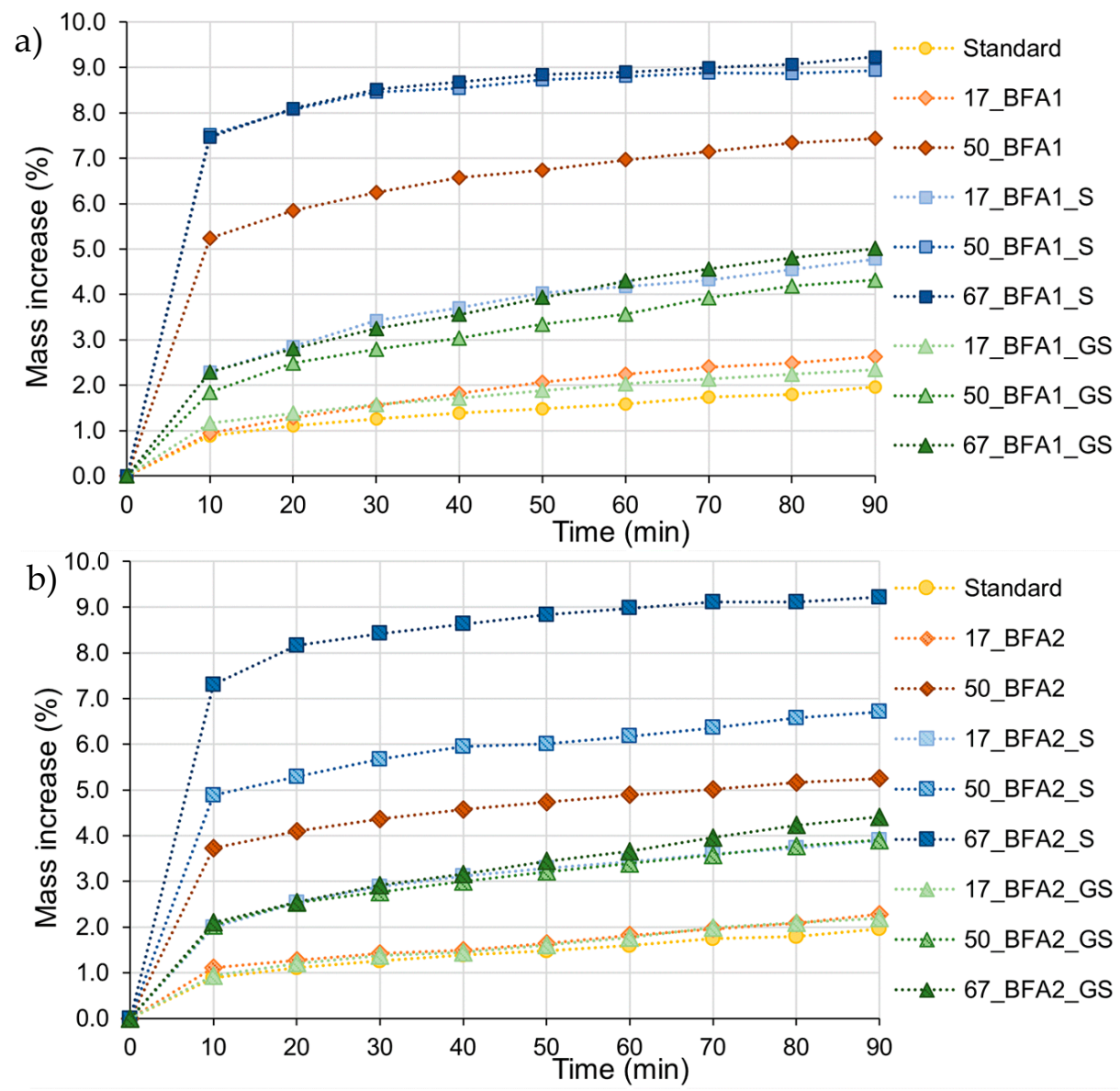

Figure 6. Capillary water absorption of the mortars (cured for 28 days) prepared with: (a) BFA1 and (b) BFA2.

Figures 7 and 8 show the values obtained for the compressive and flexural strength of the specimens cured for 28 days, respectively. The use of BFA1 and BFA2 (as received or pre-treated) as OPC substitute promote, in general, a deterioration of the mechanical properties. The same result was achieved by other authors $[4,6,23,24]$. The mechanical resistance of the specimens prepared with the as-received ashes is as lower as higher is the ash amount, as reported in previous works $[4,6,18,23]$. However, the decrease is much smaller for the lower (17 wt.\% of OPC) than for the higher (50 wt.\% of OPC) ash content.

The incorporation of pre-treated ashes (sieved and grounded and sieved) did not affect so strongly the mechanical properties of the specimens. The samples in which $17 \mathrm{wt} . \%$ of the OPC was replaced by the pre-treated ashes have mechanical properties quite similar to the standard formulation. This behaviour is clearer for the specimens that incorporate BFA2, as they have higher density and lower water absorption values.

The target application requires, as minimum values for flexural and compressive strength, $3 \mathrm{MPa}$ and $10 \mathrm{MPa}$, respectively. The samples that satisfy these requirements are the ones in which $17 \mathrm{wt}$ \% of OPC was replaced by the as-received or the pre-treated BFA (sieved and grounded and sieved). Samples containing 50 wt.\% BFA2_GS show flexural strength $(3.6 \mathrm{MPa})$ satisfying the requirement for a commercial screed. The better compactness of these samples can explain this behaviour. 


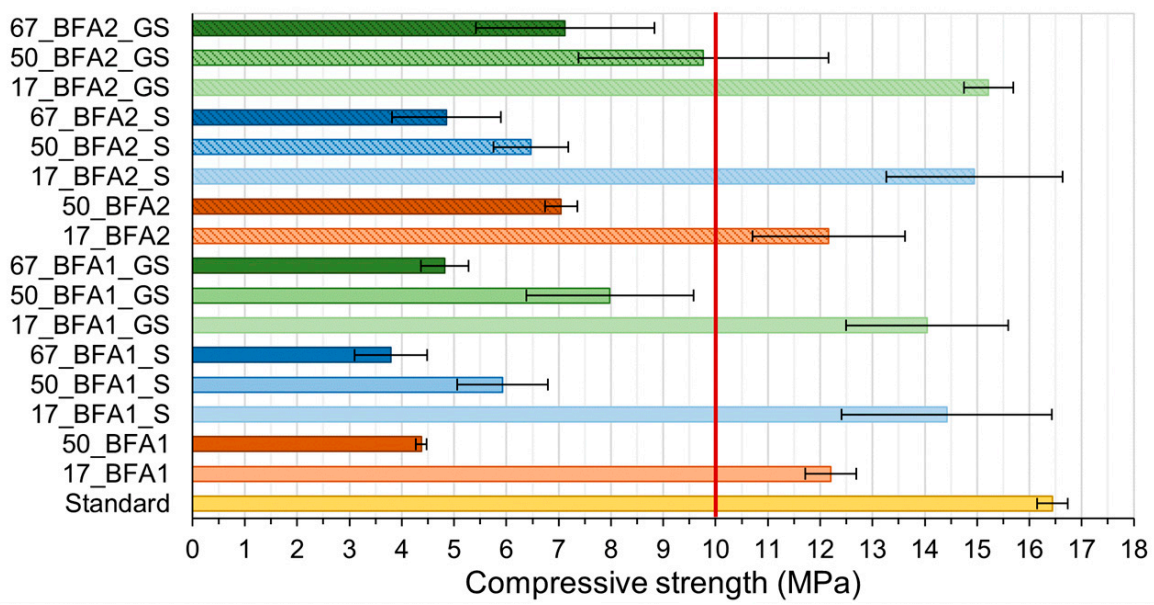

Figure 7. Compressive strength of the mortars cured for 28 days, compositions prepared with BFA1 and BFA2. The red line represents the minimum values required for the target application.

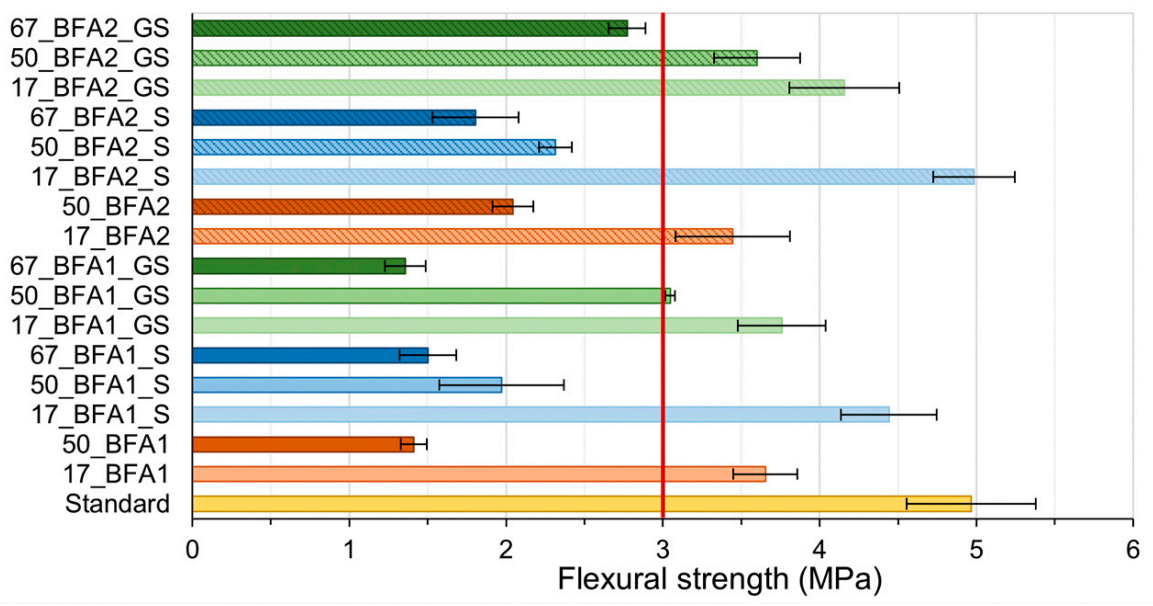

Figure 8. Flexural strength of the mortars cured for 28 days, compositions prepared with BFA1 and BFA2. The red line represents the minimum values required for the target application.

The satisfactory results obtained in this work with $17 \mathrm{wt} . \%$ OPC substitution by as received BFA, are in agreement with other studies that pointed for $20 \mathrm{wt} . \%$ OPC replacement as the maximum recommended level $[4,6,19,23,24]$. Fořt et al. [18] suggested $30 \mathrm{wt} . \%$ as maximum OPC replacement level. It should be noted that Rajamma et al. [4] used sieved BFA $(<75 \mu \mathrm{m})$ and Ohenoja et al. [24] used classified and ground BFA, to achieve such results.

Figure 9 shows the effect of OPC content decrease, replaced by BFA, on compressive strength values. Predicted reduction for the standard formulation was also estimated (yellow cycles and dotted line), simply assuming the effect of binder reduction in the mixtures. This way we aim to detect if BFA has positive or negative effects on the mechanical strength of the mixes.

Samples containing $17 \mathrm{wt}$.\% BFA tend to show slightly higher compressive strengths than predicted from the OPC reduction, excepting the blend prepared with BFA1. This behaviour might reflect the poor compactness of this sample, being also a confirmation of the poor hardening potential of BFA1. Pre-treated ashes show suitable particle size distribution and samples are denser and more homogeneous. With higher replacement rates, the mentioned mixing difficulties and workability loss generate poorly compact samples. As a consequence, their mechanical strength values tend to be lower than the estimations based on the cement replacement. The only exception is the sample prepared 
with BFA2_GS (green open triangle), due to the narrow size distribution and suitable shape of ash particles, and its hardening potential (see Table 2).

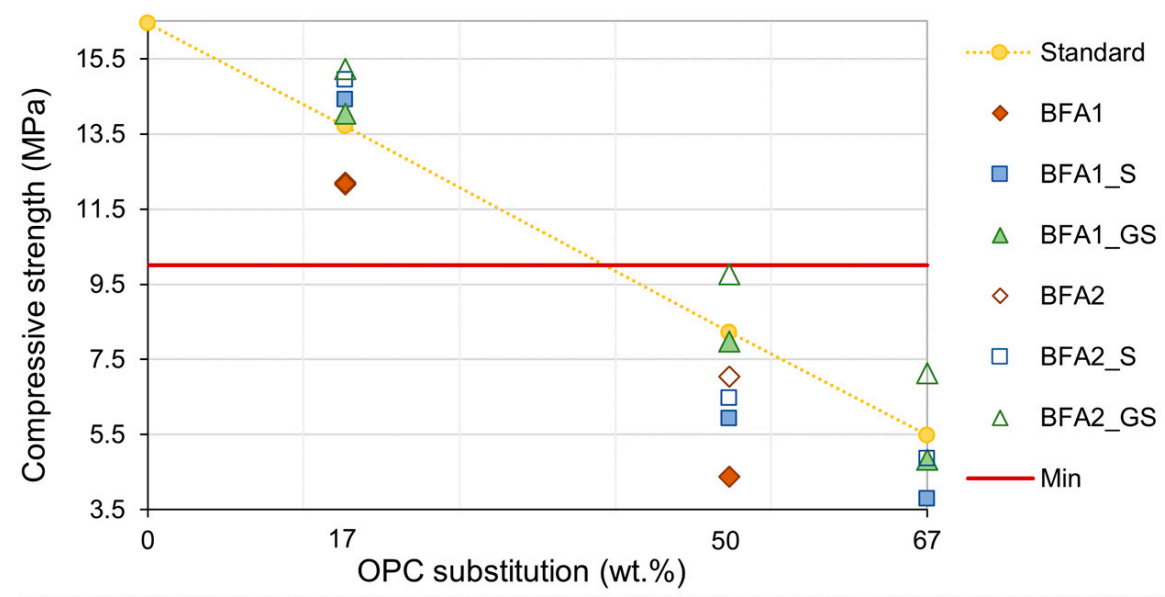

Figure 9. Effect of OPC content decrease on the compressive strength of screed mortars (cured for 28 days). Estimations assuming the strength declining simply based on the OPC amount decrease on the standard formulation are also represented (yellow circles and dotted line). The red line represents the minimum values required for the target application.

The amount of $\mathrm{SiO}_{2}+\mathrm{Al}_{2} \mathrm{O}_{3}+\mathrm{Fe}_{2} \mathrm{O}_{3}$ is equal for BFA1 and BFA1_GS (see Table 2), so it was expected same pozzolanic activity, which could not be confirmed by the obtained results. However, the milled ashes present a compressive strength slightly superior to the as-received BFA. A fact that can foresee a positive contribution of particle size reduction on their reactivity. It is possible that the contribution of BFA to the screed mortars strength improvement occurs for longer curing times, or, as suggested by Berra et al. [38] that the pozzolanic activity is not directly proportional to the $\mathrm{SiO}_{2}+\mathrm{Al}_{2} \mathrm{O}_{3}+\mathrm{Fe}_{2} \mathrm{O}_{3}$ amount (determined by the chemical analysis) but to their amorphous content.

\subsection{Freeze-Thaw Resistance}

The standard, 17_BFA1 and 17_BFA2 were subjected to freeze-thaw cycles. The values of density, water absorption and compressive strength of the specimens subjected to 0 , 5,15 , and 25 consecutive freeze-thaw cycles together with the ones of a control sample (cured in normal conditions) are presented in Table 3. The compressive strength values increased for the samples subjected to the freeze-thaw cycles and for the control. However, the variation was stronger on specimens that underwent the cycles. This may mean that the hardening of the samples keeps going after 28 days of curing and that they benefit from contact with water during the immersion phase. After 28 days of curing, 17_BFA1 and $17 \_B F A 2$ samples have similar compressive strength values ( $\left.\approx 12 \mathrm{MPa}\right)$; however, at the end of 25 cycles, 17_BFA2 exhibit higher (19.45 MPa) compressive strength than 17_BFA1 (16.44 MPa). This may indicate that given the BFA2 chemical composition (see Table 2), some hydraulic reactions have occurred during this period. The smaller particle size of BFA2, when compared to BFA1, is also beneficial for a higher reactivity. No significant variations on the density and water absorption values were observed for the three tested compositions (standard, 17_BFA1 and 17_BFA2) along with the durability tests. The water absorption values of 17_BFA1 and 17_BFA2 specimens remained always very close but higher than the standard. The density of the standard samples was always higher than that of the 17_BFA1 and 17_BFA2 samples. 
Table 3. Density, water absorption and compressive strength of samples subjected to $0,5,15$, and 25 consecutive freeze-thaw cycles and of the control samples with the same age.

\begin{tabular}{|c|c|c|c|c|c|c|c|c|c|}
\hline & \multicolumn{3}{|c|}{ Density $\left(\mathrm{g} / \mathrm{cm}^{3}\right)$} & \multicolumn{3}{|c|}{ Water Absorption (wt.\%) } & \multicolumn{3}{|c|}{ Compressive Strength (MPa) } \\
\hline & Standard & 17_BFA1 & 17_BFA2 & Standard & 17_BFA1 & 17_BFA2 & Standard & 17_BFA1 & 17_BFA2 \\
\hline 0 cycles $^{2}$ & $1.94 \pm 0.02$ & $1.86 \pm 0.01$ & $1.85 \pm 0.04$ & $6.13 \pm 0.05$ & $6.88 \pm 0.10$ & $6.60 \pm 0.33$ & $16.44 \pm 0.29$ & $12.20 \pm 0.48$ & $12.16 \pm 1.46$ \\
\hline 15 days & $1.90 \pm 0.01$ & $1.84 \pm 0.03$ & $1.86 \pm 0.03$ & $6.52 \pm 0.18$ & $7.26 \pm 0.39$ & $7.05 \pm 0.26$ & $17.99 \pm 2.05$ & $12.15 \pm 3.05$ & $14.26 \pm 2.37$ \\
\hline 5 cycles & $1.91 \pm 0.02$ & $1.84 \pm 0.05$ & $1.86 \pm 0.03$ & $6.07 \pm 0.16$ & $6.81 \pm 0.29$ & $6.79 \pm 0.33$ & $22.35 \pm 1.39$ & $15.15 \pm 3.28$ & $18.50 \pm 0.89$ \\
\hline 45 days & $1.90 \pm 0.01$ & $1.88 \pm 0.01$ & $1.89 \pm 0.02$ & $6.43 \pm 0.08$ & $6.73 \pm 0.08$ & $6.91 \pm 0.08$ & $20.40 \pm 1.05$ & $14.21 \pm 0.48$ & $16.19 \pm 0.25$ \\
\hline 15 cycles & $1.91 \pm 0.02$ & $1.83 \pm 0.02$ & $1.86 \pm 0.03$ & $6.35 \pm 0.16$ & $7.48 \pm 0.20$ & $7.24 \pm 0.04$ & $22.02 \pm 3.97$ & $14.59 \pm 0.89$ & $17.70 \pm 1.12$ \\
\hline 75 days & $1.94 \pm 0.02$ & $1.82 \pm 0.00$ & $1.87 \pm 0.03$ & $5.95 \pm 0.15$ & $6.35 \pm 0.14$ & $6.38 \pm 0.06$ & $20.42 \pm 1.07$ & $14.48 \pm 0.47$ & $15.47 \pm 0.69$ \\
\hline 25 cycles & $1.91 \pm 0.02$ & $1.85 \pm 0.03$ & $1.86 \pm 0.03$ & $5.89 \pm 0.06$ & $6.59 \pm 0.21$ & $6.64 \pm 0.15$ & $22.50 \pm 1.47$ & $16.44 \pm 2.73$ & $19.45 \pm 0.70$ \\
\hline
\end{tabular}


Figure 10 shows photographs of the samples after 0, 5, 15, and 25 freeze-thaw cycles. Macroscopically, there was no surface degradation, and no detachments, efflorescence, or cracks were observed. The three studied compositions show to be resistance to 25 freezethaw cycles, therefore the substitution of $17 \mathrm{wt} . \%$ of OPC by BFA 1 and BFA 2 does not reduce their freeze-thaw resistance.

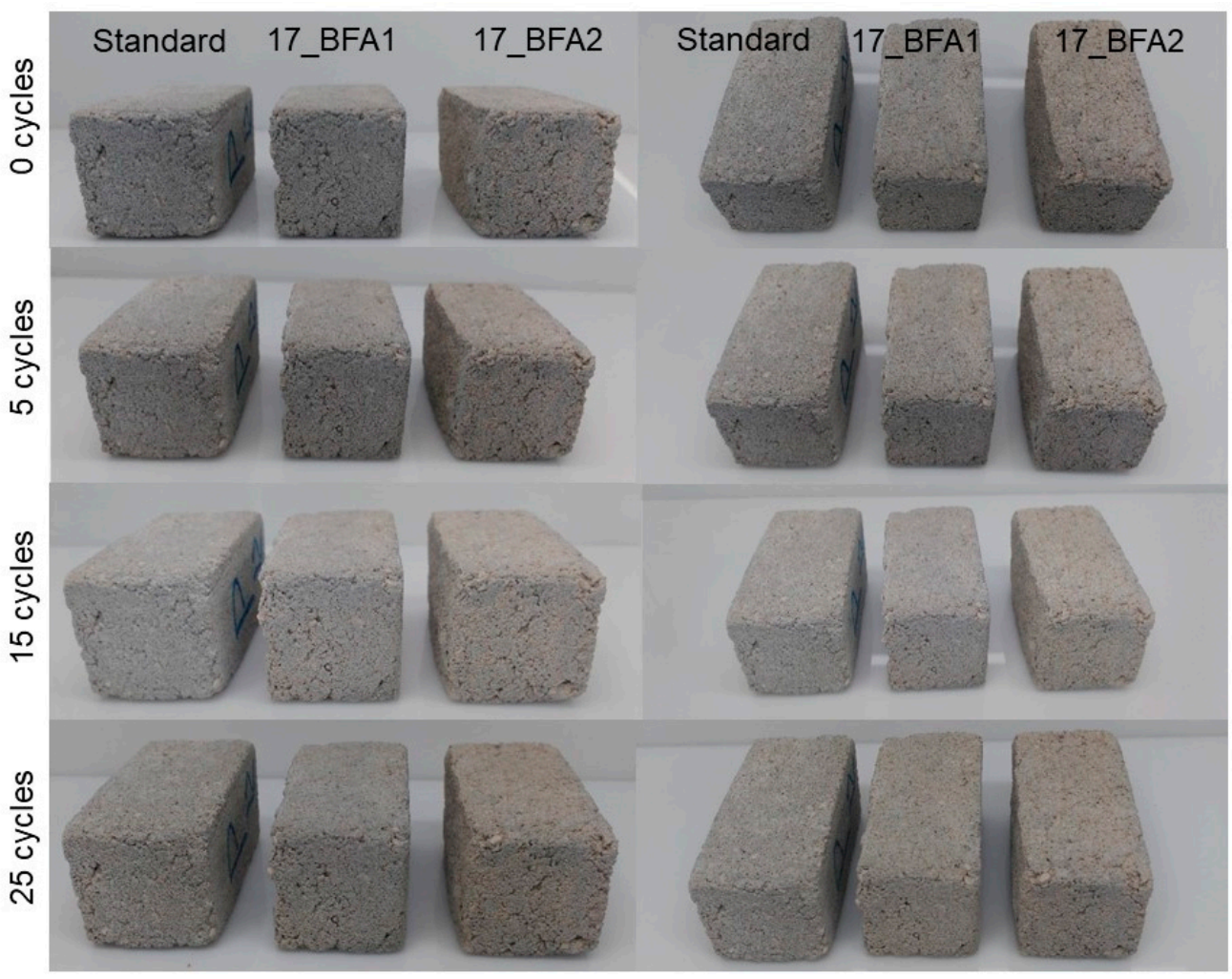

Figure 10. View of the samples after $0,5,15$ and 25 freeze-thaw cycles.

Omran et al. [17] also achieved good results for freeze-thaw resistance of BFA containing concretes. Specimens $(75 \mathrm{~mm} \times 75 \mathrm{~mm} \times 350 \mathrm{~mm})$, cured for 14 and 77 days, with 15-25 wt.\% substitution of OPC (Type GU) by BFA resisted to 300 freeze-thaw cycles (temperature variation from $-18{ }^{\circ} \mathrm{C}$ to $4{ }^{\circ} \mathrm{C}$ ). This behaviour was attributed to the decreased permeability of the BFA containing compositions.

The influence of other supplementary cementitious materials in a screed durability was reported by Reiterman et al. [39]. These authors evaluated the effect of OPC (52.5 R) replacement (from 2.5 up to $50 \mathrm{wt} . \%$ ) by ceramic powder, blast slag furnace and FA, in samples cured for 28 and 90 days, and subjected to 50 freeze-thaw cycles resistance. They concluded that the maximum incorporation amount is $12.5,37.5$ and $50 \mathrm{wt} . \%$ for ceramic powder, FA and blast furnace slag, respectively.

\section{Conclusions}

The workability of the mixtures tends to diminish when the content of biomass fly ash (BFA), as received and sieved, increases, which leads to difficulties in the mixing process. Consequently, mortars with increasing levels of BFA, presented lower density, higher water absorption, and lower compressive and flexural strengths due, not only to the lower Ordinary Portland Cement (OPC) content but also to the higher porosity.

The use of grounded BFA (with narrower particle size distribution and a smaller number of elongated particles) attenuates this trend by promoting a better homogenization of the mixtures and improving the compactness of the mortars. After curing, the obtained specimens present densities and water absorption values closer to the standard composition, even when a higher OPC percentage is replaced (67 wt.\%). 
The obtained results show that the partial substitution (17 wt.\%) of OPC, used in a commercial screed mortar formulation, by BFA is possible. The mechanical strength of the developed product and of the standard are similar. Moreover, the developed specimens are resistant to 25 freeze-thaw cycles.

The use of BFA, as an OPC substitute, in non-structural construction materials is a way to reduce these cement-based materials' environmental footprint and, at the same time, contributing to the development of a circular economy. Furthermore, economic benefits can also be achieved through the elimination of the landfilling costs of BFA and by decreasing the raw materials costs.

Author Contributions: Conceptualization, M.P.S.; methodology, M.N.C., M.P.S. and J.A.L.; validation, M.N.C., D.M.T., M.P.S., L.A.C.T. and J.A.L.; investigation, M.N.C. and M.P.S.; resources, M.P.S., L.A.C.T. and J.A.L.; data curation, M.N.C. and D.M.T.; writing-original draft preparation, M.N.C.; writing-review and editing, M.N.C., D.M.T., M.P.S., L.A.C.T. and J.A.L.; supervision, M.P.S.; project administration, M.P.S., L.A.C.T. and J.A.L.; funding acquisition, M.P.S., L.A.C.T. and J.A.L. All authors have read and agreed to the published version of the manuscript.

Funding: This work was supported by Portugal 2020 through the European Regional Development Fund (in the frame of Operational Competitiveness and Internationalization Program) in the scope of the project INPACTUS, POCI/01/0247/FEDER/21874 and in the scope of the project CICECO, UIDB/50011/2020 and UIDP/50011/2020 cofinanced by national funds through the FCT/MEC. Thanks are due to FCT/MCTES for the financial support to CESAM (UIDP/50017/2020 and UIDB/50017/2020) through national funds.

Institutional Review Board Statement: Not applicable.

Informed Consent Statement: Not applicable.

Data Availability Statement: Not applicable.

Acknowledgments: The authors gratefully acknowledge Weber Saint-Gobain Portugal and The Navigator Company for providing the Ordinary Portland Cement, sands and limestone and fly ash from the fluidized bed biomass boilers (BFA1 and BFA2), respectively.

Conflicts of Interest: The authors declare no conflict of interest.

\section{References}

1. Rodrigues, F.A.; Joekes, I. Cement industry: Sustainability, challenges and perspectives. Environ. Chem. Lett. 2010, 9, 151-166. [CrossRef]

2. Benhelal, E.; Shamsaei, E.; Rashid, M.I. Challenges against $\mathrm{CO}_{2}$ abatement strategies in cement industry: A review. J. Environ. Sci. 2021, 104, 84-101. [CrossRef] [PubMed]

3. Pavlíková, M.; Zemanová, L.; Pokorný, J.; Záleská, M.; Jankovský, O.; Lojka, M.; Sedmidubský, D.; Pavlík, Z. Valorization of wood chips ash as an eco-friendly mineral admixture in mortar mix design. Waste Manag. 2018, 80, 89-100. [CrossRef] [PubMed]

4. Rajamma, R.; Ball, R.; Tarelho, L.A.D.C.; Allen, G.C.; Labrincha, J.; Ferreira, V.M. Characterisation and use of biomass fly ash in cement-based materials. J. Hazard. Mater. 2009, 172, 1049-1060. [CrossRef]

5. Poudyal, L.; Adhikari, K. Environmental sustainability in cement industry: An integrated approach for green and economical cement production. Resour. Environ. Sustain. 2021, 4, 100024. [CrossRef]

6. Tosti, L.; van Zomeren, A.; Pels, J.R.; Comans, R.N. Technical and environmental performance of lower carbon footprint cement mortars containing biomass fly ash as a secondary cementitious material. Resour. Conserv. Recycl. 2018, 134, 25-33. [CrossRef]

7. International Energy Agency. Technology Roadmap-Low-Carbon Transition in the Cement Industry. 2018. Available online: https:/ / www.iea.org/reports/technology-roadmap-low-carbon-transition-in-the-cement-industry (accessed on 4 October 2021).

8. Golewski, G.L.; Sadowski, T. The fracture toughness the K IIIc of concretes with F fly ash (FA) additive. Constr. Build. Mater. 2017, 143, 444-454. [CrossRef]

9. González-Kunz, R.N.; Pineda, P.; Bras, A.; Morillas, L. Plant biomass ashes in cement-based building materials. Feasibility as eco-efficient structural mortars and grouts. Sustain. Cities Soc. 2017, 31, 151-172. [CrossRef]

10. Duan, S.; Liao, H.; Ma, Z.; Cheng, F.; Fang, L.; Gao, H.; Yang, H. The relevance of ultrafine fly ash properties and mechanical properties in its fly ash-cement gelation blocks via static pressure forming. Constr. Build. Mater. 2018, 186, 1064-1071. [CrossRef]

11. Sigvardsen, N.M.; Geiker, M.R.; Ottosen, L.M. Reaction mechanisms of wood ash for use as a partial cement replacement. Constr. Build. Mater. 2021, 286, 122889. [CrossRef] 
12. Aboulayt, A.; Souayfan, F.; Roziere, E.; Jaafri, R.; El Idrissi, A.C.; Moussa, R.; Justino, C.; Loukili, A. Alkali-activated grouts based on slag-fly ash mixtures: From early-age characterization to long-term phase composition. Constr. Build. Mater. 2020, $260,120510$. [CrossRef]

13. Sandanayake, M.; Gunasekara, C.; Law, D.; Zhang, G.; Setunge, S.; Wanijuru, D. Sustainable criterion selection framework for green building materials-An optimisation based study of fly-ash Geopolymer concrete. Sustain. Mater. Technol. 2020, 25 , e00178. [CrossRef]

14. Sambucci, M.; Sibai, A.; Valente, M. Recent Advances in Geopolymer Technology. A Potential Eco-Friendly Solution in the Construction Materials Industry: A Review. J. Compos. Sci. 2021, 5, 109. [CrossRef]

15. Valente, M.; Sambucci, M.; Sibai, A. Geopolymers vs. Cement Matrix Materials: How Nanofiller Can Help a Sustainability Approach for Smart Construction Applications-A Review. Nanomaterials 2021, 11, 2007. [CrossRef] [PubMed]

16. European Commission. The Roadmap for Transforming the EU into a Competitive, Low-Carbon Economy by 2050.2011. Available online: https:/ / www.eea.europa.eu/policy-documents/com-2011-112-a-roadmap (accessed on 17 September 2021).

17. Omran, A.; Soliman, N.; Xie, A.; Davidenko, T.; Tagnit-Hamou, A. Field trials with concrete incorporating biomass-fly ash. Constr. Build. Mater. 2018, 186, 660-669. [CrossRef]

18. Fořt, J.; Šál, J.; Ševčík, R.; Doleželová, M.; Keppert, M.; Jerman, M.; Záleská, M.; Stehel, V.; Černý, R. Biomass fly ash as an alternative to coal fly ash in blended cements: Functional aspects. Constr. Build. Mater. 2021, 271, 121544. [CrossRef]

19. Ohenoja, K.; Pesonen, J.; Yliniemi, J.; Illikainen, M. Utilization of Fly Ashes from Fluidized Bed Combustion: A Review. Sustainability 2020, 12, 2988. [CrossRef]

20. Modolo, R.; Silva, T.; Senff, L.; Tarelho, L.; Labrincha, J.; Ferreira, V.; Silva, L. Bottom ash from biomass combustion in BFB and its use in adhesive-mortars. Fuel Process. Technol. 2015, 129, 192-202. [CrossRef]

21. Teixeira, E.; Camões, A.; Branco, F.; Matos, J. Effect of Biomass Fly Ash on Fresh and Hardened Properties of High Volume Fly Ash Mortars. Crystals 2021, 11, 233. [CrossRef]

22. Tarelho, L.A.C.; Teixeira, E.R.; Silva, D.F.R.; Modolo, R.C.E.; Labrincha, J.A.; Rocha, F. Characteristics of distinct ash flows in a biomass thermal power plant with bubbling fluidised bed combustor. Energy 2015, 90, 387-402. [CrossRef]

23. Rajamma, R.; Senff, L.; Ribeiro, M.; Labrincha, J.; Ball, R.; Allen, G.; Ferreira, V. Biomass fly ash effect on fresh and hardened state properties of cement based materials. Compos. Part B Eng. 2015, 77, 1-9. [CrossRef]

24. Ohenoja, K.; Wigren, V.; Österbacka, J.; Illikainen, M. Mechanically Treated Fly Ash from Fluidized Bed Combustion of Peat, Wood, and Wastes in Concrete. Waste Biomass-Valorization 2019, 11, 3071-3079. [CrossRef]

25. ISO 1762:2019. Paper, Board, Pulps and Cellulose Nanomaterials—Determination of Residue (Ash Content) on Ignition at $525^{\circ} \mathrm{C}$; ISO: Geneva, Switzerland, 2019.

26. EN 196-1:2005. Methods of Testing Cement_Part 1: Determination of Strength; CEN: Brussels, Belgium, 2005.

27. BS 8204-1:2003. Screeds, Bases and In Situ Floorings_Part 1: Concrete Bases and Cement Sand Levellings Screeds to Receive FlooringsCode of Practice; BSI: London, UK, 2003.

28. EN 1015-3:1998. Methods of Test for Mortar for Masonry_Part 3: Determination of Consistence of Fresh Mortar (by Flow Table); CEN: Brussels, Belgium, 1998.

29. EN 1015-18:2002. Methods of Test for Mortar for Masonry_Part 18: Determination of Water Absorption Coefficient Due to Capillary Action of Hardened Mortar; CEN: Brussels, Belgium, 2002.

30. EN 998-2:2016. Specification for Mortar for Masonary_Part 2: Masonry Mortar; CEN: Brussels, Belgium, 2016.

31. Gruszczyński, M.; Lenart, M. Durability of mortars modified with the addition of amorphous aluminum silicate and silica fume. Theor. Appl. Fract. Mech. 2020, 107, 102526. [CrossRef]

32. EN 450-1:2012. Fly Ash for Concrete-Part 1: Definition, Specifications and Conformity Criteria; CEN: Brussels, Belgium, 2012.

33. Modolo, R.; Ferreira, V.; Tarelho, L.A.D.C.; Labrincha, J.; Senff, L.; Silva, L. Mortar formulations with bottom ash from biomass combustion. Constr. Build. Mater. 2013, 45, 275-281. [CrossRef]

34. Maschio, S.; Tonello, G.; Piani, L.; Furlani, E. Fly and bottom ashes from biomass combustion as cement replacing components in mortars production: Rheological behaviour of the pastes and materials compression strength. Chemosphere 2011, 85, 666-671. [CrossRef] [PubMed]

35. EN 197-1:2011. Cement Part 1: Composition, Specifications and Conformity Criteria for Common Cements; CEN: Brussels, Belgium, 2011.

36. Modolo, R.C.E.; Senff, L.; Ferreira, V.; Tarelho, L.A.D.C.; Moraes, C.A.M. Fly ash from biomass combustion as replacement raw material and its influence on the mortars durability. J. Mater. Cycles Waste Manag. 2017, 20, 1006-1015. [CrossRef]

37. Rissanen, J.; Ohenoja, K.; Kinnunen, P.; Romagnoli, M.; Illikainen, M. Milling of peat-wood fly ash: Effect on water demand of mortar and rheology of cement paste. Constr. Build. Mater. 2018, 180, 143-153. [CrossRef]

38. Berra, M.; Mangialardi, T.; Paolini, A.E. Reuse of woody biomass fly ash in cement-based materials. Constr. Build. Mater. 2015, 76, 286-296. [CrossRef]

39. Reiterman, P.; Holčapek, O.; Zobal, O.; Keppert, M. Freeze-Thaw Resistance of Cement Screed with Various Supplementary Cementitious Materials. Rev. Adv. Mater. Sci. 2019, 58, 66-74. [CrossRef] 